Article

\title{
Liquefied Natural Gas as a New Hazard; Learning Processes in Norwegian Fire Brigades
}

\author{
Maria-Monika Metallinou
}

Department of Fire Safety and HSE Engineering, Glöz R\&D, Western Norway University of Applied Sciences, 5528 Haugesund, Norway; monika.metallinou@hvl.no; Tel.: +47-9882-5104

Received: 7 January 2019; Accepted: 18 February 2019; Published: 20 February 2019

Abstract: The innovation and utilization of new products leads to technological changes in contemporary societies and a need for the Fire Brigades (FBs) to update their expertise regarding the challenges these new products may represent. The present study examines learning processes for nine fire brigades in Norway, selected where Liquefied Natural Gas (LNG) facilities are in their jurisdiction and/or because they have handled LNG road accidents. The process of acquiring the necessary new knowledge and skills is researched inductively, and each FB is viewed as a unit in the Norwegian fire and rescue community, i.e., a multi-unit learning organization. Kolb's learning cycle is used to discuss the findings. Large variations in learning processes were used in the different FBs, varying from short classroom courses held by external consultants to a series of learning episodes planned and directed by FB personnel. It was found that each FB focused locally and independently from other FBs when acquiring new knowledge. There was very limited knowledge transfer from FBs experienced with LNG facilities to "newcomers". There is no established national knowledge-sharing network on LNG. There are, however, regional partner groups, mainly involving the FB and a distribution company, mentioned by all studied FBs to be the most important partner for learning. The inter-municipal committee against acute pollution (IUA) was the second most important learning cooperation partner. It was, however, discovered that LNG test releases gave rise to observations regarding the extension of the flammable cloud versus the visible cloud that was interpreted wrongly due to the lack of theoretical understanding of the influence of the air relative humidity. This was explained to one regional partner group that invited, and therefore asked, an academic about this issue during a training session. This partner group arranged demonstrations for all FBs involved along the path of LNG transport from the production site to their end-users. Surprisingly, there was very limited knowledge exchange between partner groups in different geographical regions, though one of these was certainly more knowledgeable. The present study revealed that knowledge sharing must be improved, at least when it comes to potential LNG incidents.

Keywords: LNG accidents; fire brigades; learning processes

\section{Introduction}

Life-long learning is inevitable in all types of organizations, following societal and technological development. Most organizations consist of several units performing similar activities in different geographical areas, described as multi-unit organizations. Research reveals that there are great differences in whether or not units in the same organization communicate and exchange knowledge [1]. It is commonly accepted that both related knowledge and a set of sharing mechanisms (centrally coordinated or through lateral links) seem necessary for knowledge sharing to occur between units, which then form a knowledge network [2-6].

In Norway, FBs are organized as municipal or inter-municipal companies, subject to laws and regulations from the Ministry of Justice and Public Security (MJP) and the Directorate of Civil Protection 
(professional authority). FBs share related duties, which implies that they share related knowledge and skills, as well as commitment and culture. Therefore, the Norwegian fire and rescue community is considered a multi-unit organization, consisting of numerous FBs (units). More knowledge-based incident handling is a political goal in Norway, which is currently restructuring the education of fire responders [7]. However, knowledge about every possible hazard cannot be included in the basic education, whose length is limited. Besides that, life-long learning and further education must always be addressed, as hazards threatening societies, technological as well as natural, may change rapidly. The maintenance and updating of knowledge and skills in FBs is imposed by Norwegian law and is primarily a municipal responsibility [8].

Sommer and Njå [9] studied learning amongst Norwegian Fire Fighters, mainly focusing on the novices' development from peripheral participants towards full responsibility. However, mechanisms used by FBs for updating the unit's competence in new challenges have not been extensively researched.

Research indicates that commanders facing unfamiliar hazards experience additional uncertainty during responses and may become reluctant to make decisions while waiting for experts to provide estimates. This results in a slower and perhaps less efficient response. There is evidence suggesting that incident planning could be improved by enhancing emergency managers' knowledge of the hazards and threats they may face [10-12]. Responders may feel uncomfortable with uncertainties about the material properties of a new hazard, or overconfident, based on similar, but not fully relevant, knowledge. Being overconfident but not knowledgeable about new challenges may lead to the wrong handling of the situation, with unforeseen severe consequences.

LNG consumption in Norway has grown exponentially during the last few years, increasing the number of production and storage sites, as well as the need for road transportation. LNG is a hazardous chemical with resemblances to, but also differences from, other hydrocarbons that FBs are more familiar with, e.g., liquefied petroleum gas (LPG). Centrally organized updating courses on new hazards do not exist in Norway. Knowledge on how FBs proceed to acquire knowledge on new hazards (analyzed with Kolb's learning theory [13]), can inform political processes aiming to facilitate future FB learning. It can also provide useful input regarding the necessary competencies that graduates from the Norwegian Academy should possess, in order to succeed with life-long learning.

To reveal how Norwegian FBs update their knowledge on new challenges, LNG is chosen in the present study as the new challenge. Nine FBs have been contacted for interviews seeking answers to the following research questions:

1. Which circumstances trigger FBs to perceive the need to acquire knowledge about LNG?

2. How do different units (FBs) proceed in their learning efforts?

3. Which actors/institutions do FBs cooperate with, when they organize their learning projects?

4. Do Norwegian FBs facing common LNG challenges cooperate about learning, thus forming learning networks?

The study explores organizational learning and workplace learning, without exhausting the subject of how Norwegian FBs update their knowledge and skill. The revealed processes may be indicative of the way FBs update their knowledge and skill, with respect to new hazards in general, and therefore have generic value. However, that will need verification through further research.

The present study is positioned in the area of on-the-job learning and, specifically, learning in emergency response work. Through a comparative case study among nine FBs, it reveals learning motivations and strategies, and provides information on further needs. What they achieve through the current strategies and where they have shortcomings, thus needing assistance from external actors, are revealed. Why LNG is chosen as an indicator hazard is explained in Section 2, including nuances between LNG and more familiar flammable chemicals. The theories and methods are explained in Section 3, along with a description of the relevant laws and regulations. The theoretical background for the study is presented in Section 4, and the methods used in the study, in Section 5. Section 6 presents and discusses the findings, extensively outlining the in-depth learning process undertaken by one 
particular FB, their regional cooperation partners and the performed learning processes. The main conclusions are summarized in Section 7.

\section{LNG Hazards}

\subsection{LNG Consumption}

There has been an exponential growth in the LNG share in the energy mix of the USA [14], Europe [15], and Asian countries [16], mainly market driven. A similar development is also being experienced in Norway, where it is primarily environmentally primed $[17,18]$. Being $30 \%$ behind schedule for NOx emissions, according to the 1999 Gothenburg Protocol, Norway introduced a NOx tax in 2007. The tax was assigned to the NOx Fund, which supports NOx-free technologies for industrial users. This propelled LNG consumption and resulted in an exponential growth from 2007 to 2017, simultaneously reducing NOx pollution [19].

Converting from oil to LNG for several types of land-based industry, as well as shipping to some extent, the LNG consumption in Norway increased from 28,000 tons per year in 2004 to 145,000 tons in 2014 and, further, to 440,000 tons in 2017 [19,20]. Increased consumption implies increased number and size of local storage installations, as well as increased need for transportation by sea and road. The probability of incidents involving LNG, during both transport and handling, has therefore increased considerably.

\subsection{Physical Properties of $L N G$ and Associated Hazards of Spills}

LNG is a cryogenic flammable liquid, mainly consisting of methane. At 1 bar, the liquefaction temperature is $-163{ }^{\circ} \mathrm{C}$. The density of the liquefied state is 600 times higher than the gaseous state, making cryogenic condensation an effective way for natural gas transport. The lower flammability limit (LFL) for methane in air is 5\% by volume, and the upper flammability limit (UFL) is $15 \%$ [21]. The main differences between LNG and other liquid hydrocarbons is the large temperature difference between the product and the surroundings, and the high vapor pressure at ambient temperatures. The LNG therefore must be transported in very well-insulated pressure containers, which cannot withstand the vapor pressure at ambient temperatures. There are two methods of preventing heat gain from the surroundings: either a vacuum between an inner and outer tank or insulating the tank with self-extinguishing expanded polyurethane, covered by an external aluminum shell. Both methods are approved designs for LNG transportation. However, even in highly insulated containers, LNG will gradually vaporize and must be regularly consumed or flared, in order not to result in tank overpressure. Road incidents involving LNG are therefore accompanied by a time pressure, which must be dealt with, even in situations where there is no fire involved. This is especially the case if the insulation is damaged. If the pressure relief valve is damaged, the incident may likely develop into Boiling Liquid Expanding Vapor Explosion (BLEVE), even without an external fire.

Immediate hazards of LNG leaks may include cryogenic injuries to people [22] and brittle failure of materials exposed to cryogenic temperatures [23]. A short description of the Cleveland LNG accident in 1944 and four cases of LNG spills on deck plates of cargo vessels during unloading, which all cracked, are described in [23]. The spread of LNG spill on the ground depends on the topography of the area and climatic conditions. The density of LNG is about half the density of water. When vaporized at $-163{ }^{\circ} \mathrm{C}$, the vapor density is about 1.5 times the density of air at $20^{\circ} \mathrm{C}$. A pool of LNG will spread out and boil in contact with the ground. If immediately ignited, a pool fire will occur, while a late ignition results in a vapor cloud fire/explosion, which burns back to the pool [24].

The radial thermal emission of large LNG pool fires was studied through a series of large-scale experiments with the largest diameter about $35 \mathrm{~m}$ [25]. The results showed that the flame is clean and yellow for pools of up to $13 \mathrm{~m}$ in diameter and becomes sooty for larger diameters due to oxygen starvation in the center. Spectral analysis was also performed. Sandia National Laboratory, Albuquerque, New Mexico, performed the most recent large-scale experiments in 2009 [26]. From a 
pool with equivalent circular diameter of about $81 \mathrm{~m}$, and mass discharge rate of about $800 \mathrm{~kg} / \mathrm{s}$, a flame with ca. $146 \mathrm{~m}$ height and $50 \mathrm{~m}$ width (at approximately $15 \mathrm{~m}$ above the pool) was obtained. The obtained data and photographs have been used to validate Computational Fluid Dynamics (CFD) codes that predict the behavior of large LNG fires [27]. However, one of the aims of emergency responders handling an incident with spilled LNG is to prevent ignition. Therefore, the geometry of the envelope with flammable concentration compared to the visible cloud is of crucial interest.

\subsection{Visible Cloud Boundary Versus the Flammability Limits}

From 1973 to 1992, several large-scale experimental LNG release experiments were conducted under climatic conditions varying between dry desert climate and humid seashore conditions [28,29]. It was observed that the visible cloud varied considerably under different conditions for similar spills. In most field tests conducted with LNG vapor clouds, no cloud lift-off was observed before the cloud concentration at ground level was diluted to values lower than the LFL [30]. Since the density of vaporized methane at $-163{ }^{\circ} \mathrm{C}$ is about 1.5 times the density of air at $20^{\circ} \mathrm{C}$, the methane cloud spreads along the ground. While mixing air with cold methane vapor, the air is cooled below the dew point temperature, resulting in humidity condensing to water droplets or freezing to ice crystals, dependent on the resulting temperature. This cold air/methane mixture is heavier than the ambient air. External heat sources, e.g., the ground or sun radiation, are necessary to increase the temperature and cause the air/methane to lift off. The resulting visual clouds from major experimental LNG releases, sliding along the ground, can be found in Koopman and Ermak [31]. A 70-80 m-long visible cloud from a training session at Polarbase, Hammerfest, Norway, is shown in Figure 1.

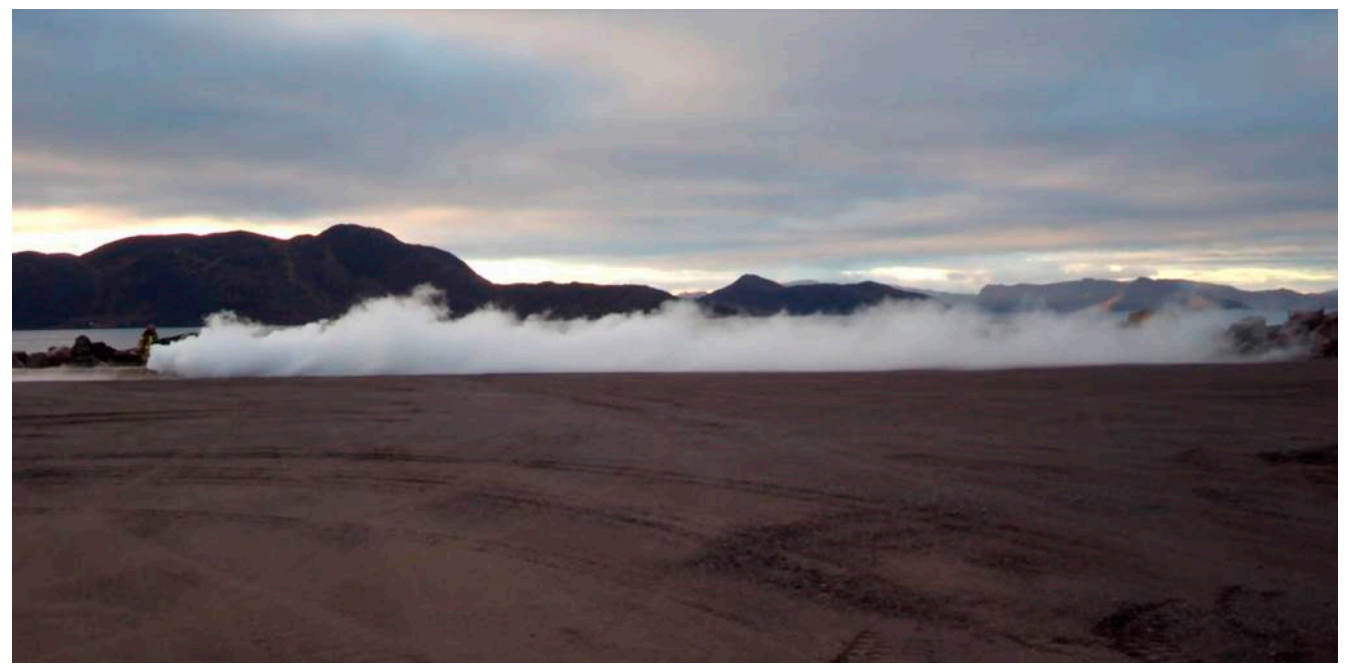

Figure 1. Hammerfest test site, Norway, at $70.63^{\circ}$ N. (Photo by Torgrim Log, reproduced with permission)

In low relative humidity $(\mathrm{RH})$ conditions, i.e., $5-23 \% \mathrm{RH}$, flammable clouds were observed to be larger than the visible clouds [32,33] and, during testing at $52-83 \% \mathrm{RH}$, the visible cloud extended further downwind than the flammable cloud [34]. The importance of the RH on the visible versus flammable cloud extension was further investigated by Vílchez et al. [35]. At about 50\% RH, the visible cloud and the flammable cloud coincide, and a dispersion safety factor for other conditions was provided for, as vital information for the emergency responders.

\subsection{Overview of LNG Accidents}

Compared to other fuels, there have been few LNG accidents in production and storage sites, with four major incidents till 2005 worldwide reported in [36]. However, overfilling accidents do occur, e.g., the Norwegian Petroleum Authority reported an overfilling accident involving a road tanker at a production plant in Norway in 2018 [37]. 
Overseas transportation also has a good record compared to other ship transport, with no incidents involving the loss of LNG cargo. However, less severe incidents have occurred. A Norwegian LNG tanker, grounded on a reef in the North Atlantic in 2017, suffered water ingress but was refloated by its own means [38]. Most reported leakages have occurred during the loading/unloading of cargo [23]. The potential for terror attacks may also represent a very serious threat that could turn LNG ships into bombs [39].

Road transportation in Europe has suffered two LNG BLEVEs, in 2002 and 2011, both in Spain. The accident in 2002 was an overturning accident in a downhill road section [40]. The accident in 2011 was caused by driving too close past a stationary heavy goods vehicle (HGV) loaded with concrete elements [41]. The tanks involved in the mentioned accidents (diameter $2.33 \mathrm{~m}$ and length $13.5 \mathrm{~m}$ ) had an inner tank of stainless steel AISI-304 of $4 \mathrm{~mm}$ wall thickness and $6 \mathrm{~mm}$ wall thickness at both ends. These tanks were insulated with self-extinguishing $130 \mathrm{~mm}$ thick expanded polyurethane, covered by a $2 \mathrm{~mm}$ aluminum shell.

\subsection{LNG Road Accidents in Norway}

Norway has experienced three incidents during the last 10 years, varying from incidents that were easily handled to situations that could have developed into a BLEVE. These incidents are described below.

\subsubsection{Vallaheiane, Hordaland, 2010}

A road tanker, loaded with 17 tons of LNG, overturned and lay on the road shoulder close to the town of Os, on 14th May 2010. The road section where it overturned is characterized by slope and sharp curves, and (as tanks have only cross-sectional and not longitudinal baffles) liquid movements may have contributed to the overturning. The valves for the possible transfer of the cargo to another tanker were not accessible, due to the overturning [42]. When righted, with punctured vacuum insulation, the semi-trailer was connected to a new truck and escorted by the police and the fire brigades (FBs) through the evacuated area to the customer for cargo offloading. The operation lasted about $13 \mathrm{~h}$.

\subsubsection{Vinje, Telemark, 2011}

In Vinje, on 16th February 2011, a driver maneuvered the road tanker slightly too far to the side on a narrow road, in order to make space for an approaching HGV. Since the road was covered by snow, which was piled on the road shoulder, it was not possible to know where the road shoulder ended. The road tanker tilted and leaned onto the adjacent rock, which prevented an overturn incident [43]. Temperatures on the outer shell indicated no puncturing, but the cargo was loaded over to another tank before the road tanker was put back on the road. Besides making the lift easier, the concern regarding the possible puncturing of the outer shell during the lifting operation was the reason for cargo transfer.

\subsubsection{Gvarv/Ulefoss, Telemark, 2015}

The third accident occurred between Gvarv and Ulefoss on 13th October 2015 [44]. The road tanker drove off the road and overturned in steep terrain, stopping when arrested by a large tree penetrating the window of the driver's cabin (Figure 2). The full LNG tank came loose and rolled further down the slope to flat terrain $30 \mathrm{~m}$ from the road and at 5-m lower elevation. The outer shell was damaged against rocks, thus puncturing the vacuum protection. The longest rift was $1 \mathrm{~m}$ long. The tank finished upside down, i.e., the pressure relief valve would release liquid if the PSV set point pressure was reached, i.e., 6 barg. The complete operation, during which approximately 30 tons LNG were flared, lasted $46 \mathrm{~h}$, involving several cooperating companies and emergency response organizations. 


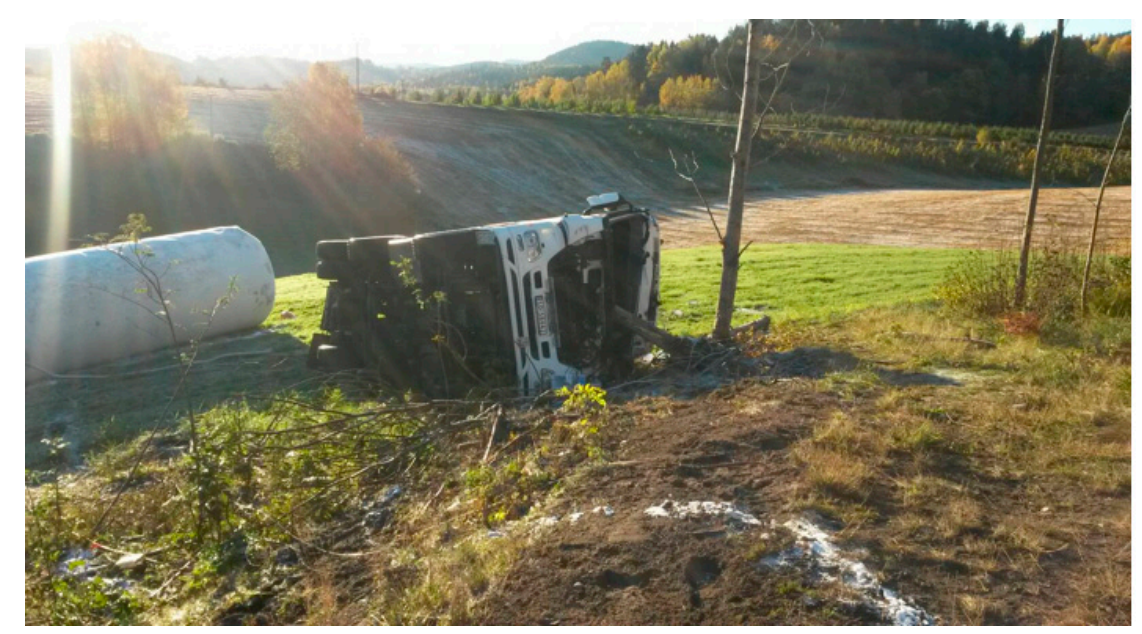

Figure 2. LNG transport accident, Gvarv, Norway, 2015. (Photo by Roar Smukkestad, reproduced with permission)

\section{Relevant Laws and Regulations Affecting Learning in FBs}

The law imposing municipal risk and vulnerability analysis [45] (MJP 2011) aims at identifying and analyzing technological and natural risks which may affect the municipality. In cases where hazardous substances are involved, an additional and more specific law applies-the Seveso major accident regulation [46]. Fire brigades also perform their own risk and vulnerability analysis, to review the potential hazards they may face. Thus, they uncover areas where they need to acquire (or increase) knowledge and skills, as well as necessary equipment. The Ministry of Justice, through the Directorate of Civil Protection (DSB), governs the Norwegian fire brigades. The DSB has the role of a "professional authority", implying that it shall be able to guide fire brigades in technical, practical and scientific matters. The Norwegian Fire Academy, offering basic education and training, is subject to the DSB, which also publishes instructional documents for emergency response organizations and arranges hazardous materials conferences.

Organizing fire brigades is a municipal responsibility, guided by the fire and explosion protection law and regulations $[8,47,48]$. FBs are therefore a part of the local community, as well as a unit in the national fire and rescue "organization". The regulations primarily address the number of fire fighters, according to the number of inhabitants and the number of people in villages, towns or cities. The required competence levels for the responders are also prescribed to some extent, expressed as graded positions in the FB. Upgrading fire fighters' knowledge and skills, in order to cope with new challenges, is addressed in the Guidance to Regulations on the organization and dimensioning of the fire department [49], §7.1. "The municipality shall ensure that personnel in the fire service comply with the qualifications required by this regulation. Practical and theoretical exercises with such frequency, scope and content shall be carried out, that the personnel's competence is maintained and developed so that it is sufficient for the fire service to solve the tasks that they can be expected to face." A representation of the administrative system is shown in Figure 3. 


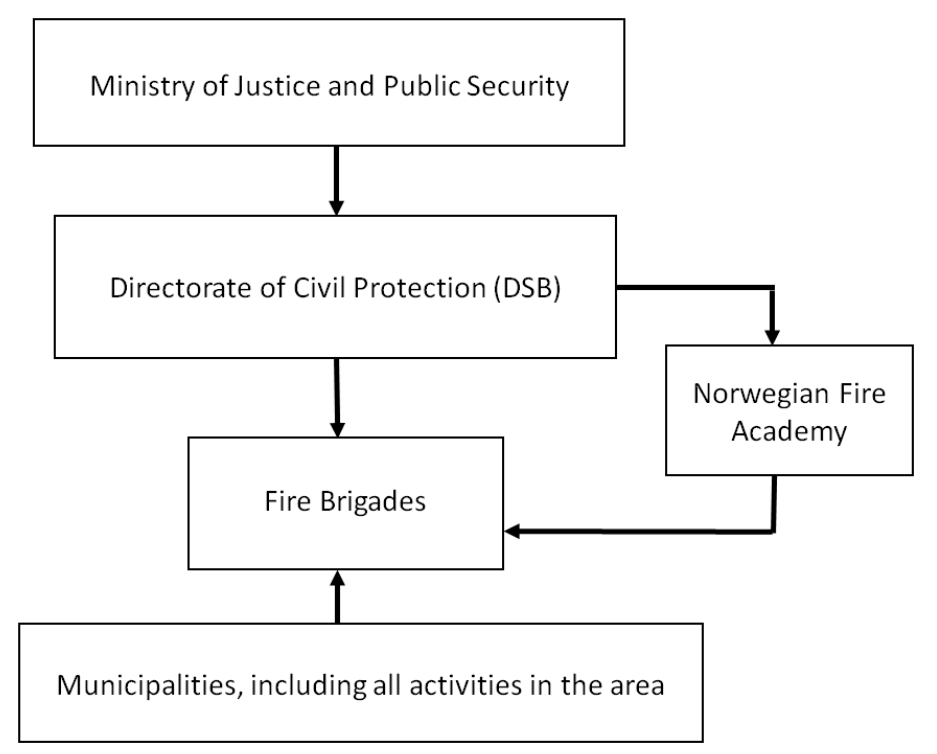

Figure 3. Municipal fire brigades in the Norwegian administrative system [8,47].

\section{Theory}

In the present work, FBs (each unit) are considered as learning organizations [50-52]. The paradigm of the learning organization acknowledges individual learning as the driving force for "enhancing and expanding collective awareness and capabilities" [53], p. 4. For the individual learner, both metaphors on learning — learning as acquisition [54-56] and as participation [57,58] —are recognized as important in the present work [59]. Sommer and Njå [9] studied learning processes in one large Norwegian FB through participant observation. They observed that, during the participant observation period, a local oil company arranged a classroom course in spill control and fire suppression of LNG for the particular FB. The responders found it valuable to learn about these issues, but "Most of them expressed the view that training courses must be practical, if they were to be really useful." Fire fighters value work-related learning and experience above initial qualification training at the fire academy $[9,60]$. Experience as a source of learning and development [13] is therefore a central learning mechanism for fire responders.

Kolb's definition, "Learning is the process whereby knowledge is created through the transformation of experience" [13], p. 49, combines the processes of (1) concrete experience (doing/having an experience), (2) reflective observation (reviewing, reflecting upon the experience), (3) abstract conceptualization (concluding, learning from the experience), (4) active experimentation (planning, trying out what has been learned). These steps are illustrated in Figure 4.

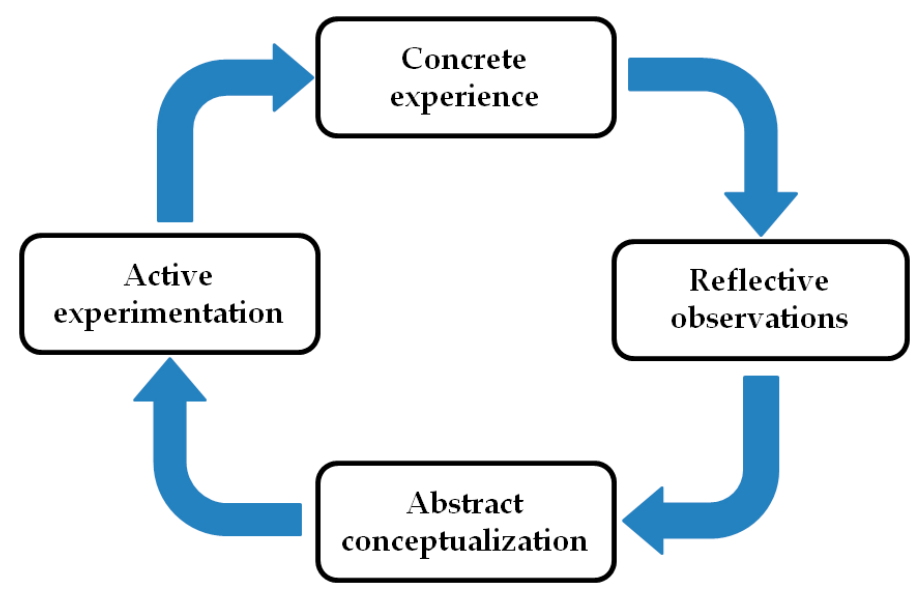

Figure 4. Sketch of Kolb's [13] learning cycle visualized. 
Since most FB duties require more than one person to manage them, shared experiences are generated. Kolb's learning cycle has been adapted for team learning by Senge et al. [53] and Kolb and Kolb [61], the respective stages being (1) coordinated action, (2) public reflection, (3) shared meaning, and (4) joint planning. In multi-unit organizations, different units perform similar activities in different geographical areas. This implies that different units may undertake parallel learning processes on the same topic. If learning cooperation is an organizational praxis, units may mutually benefit from each other. However, the learning cooperation process requires central coordination or lateral linkages to occur [1].

In the present study, FBs are studied as units, which update their competence on a particular new hazard (LNG), given that the need for that is perceived. The first stage of Kolb's learning cycle is assumed to be incident handling or a training session on LNG. The second stage, reflection, is assumed to be the process undertaken following the incident handling or training session, in the form of discussing the experience, producing their own documents summarizing the observations and communicating them to other responders who did not share the experience.

Through the basic education and training of fire responders, basic knowledge on most relevant hazards, including chemical hazards, has been established. When novel hazards are introduced, similarities and differences to other, more familiar, hazards are analyzed. This is an assimilation/accommodation process [54], performed at both the individual [56] and the unit level [62]. Such analysis is understood as the process between stage 2, reflection, and stage 3, abstract conceptualization. Abstract conceptualization is the stage in which the FBs intend to gain in-depth understanding of the properties and behavior of LNG. The fourth stage, active experimentation, implies varying relevant parameters in order to acquire generic knowledge, thus creating new experiences at a higher level. Repetitive learning cycles lead to higher competence. Kolb [13] states that effective learning only occurs when all four stages of the model are completed. Research also supports that a combination of practical and theoretical training results in enhanced competence for professionals [63,64]. Theoretical knowledge and understanding of involved phenomena support versatility in decisions and actions as parameters vary. This is important, as the ultimate goal of enhancing the competence of FBs is better incident handling and better proactive work.

\section{Methods}

First, the number of LNG-production and -storage facilities were investigated. There are currently five LNG-production facilities and approximately 70 LNG-storage facilities in Norway, often in conjunction with an important (energy-intensive) customer. It was therefore necessary to limit the sample. The five production locations, two storage locations, as well as three FBs who have handled road incidents with LNG, were selected for the study. Since one of the FBs with storage facility also had handled a road incident, the total number of studied FBs is nine. In one of the FBs the turn-over in leadership positions since the establishment of the LNG-plant was extensive. In this FB both current personnel and the retired fire chief were interviewed. This makes 10 interviews with personnel from FBs. (The particular FBs were chosen out of an expectation they that would be among the most updated and competent on LNG hazards.) The study approach was explorative, with no presupposed assumptions as to how FBs update their knowledge. Semi-structured interviews $[65,66]$ were used for data collection from nine FBs, using LNG as the indicator hazard. FBs which had conducted learning projects proactively, are not included. These FBs, if they exist, were difficult to identify. However, this may be a limitation of the study.

The questions covered aspects such as the preparatory process before the facility was established, the contingency plan (assigning the different parts' responsibilities), and the experience of the particular FB with chemical hazards. Usual learning processes in the particular FB were also analyzed, as well as important cooperation partners in these learning processes. For the FBs which handled road accidents involving LNG, the questions covered the incident itself, and whether a learning process 
was undertaken in the aftermath. Though the starting point for the learning process may differ (LNG facility or road accident), questions asked about the learning process were identical.

Since practical FB LNG-related learning activities require cooperation with a distribution company, interviewing both fire brigades and distribution companies was a way to (partly) triangulate the obtained information $[67,68]$. The four largest LNG-distribution companies, and one production company, which cooperated with the studied FBs, were also interviewed, making five interviews with companies. The questions focused on the form of learning cooperation with FBs, contingency plans, and the perceived challenge to "attract" the FBs' attention to low-probability, high-consequence hazards associated with LNG production, transport, and storage.

In total, 10 interviews were conducted with nine FBs who either had a production plant, a selected storage facility, and/or had experienced an incident, in their jurisdiction area. One of the interviews was conducted by telephone, the others at the working place of each FB.

For the LNG-distribution companies, and one production company, five interviews were conducted at their working place. The duration of the physical interviews was between 60 and $75 \mathrm{~min}$; the telephone interview lasted between 20 and $25 \mathrm{~min}$.

\section{Results and Discussion}

It should be noted that the theory described in Section 2 was not presented to any FB prior to the interviews. The learning processes of each of the studied FBs are briefly described in Table 1.

Table 1. Studied Fire Brigade (FB), responsibility, learning process, main learning partner, knowledge provider to other FBs, and possible continuing training sessions.

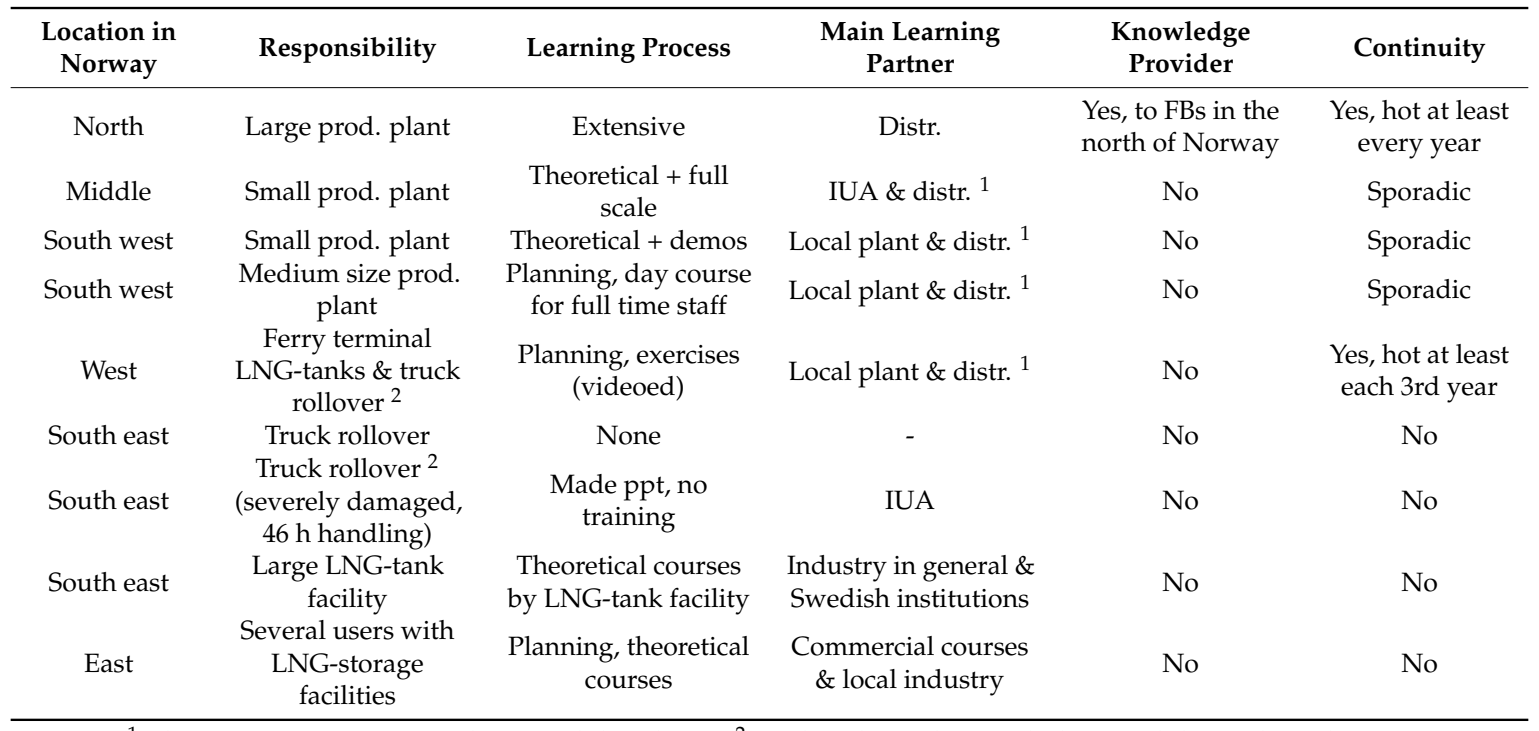

\subsection{Importance of Combining Experiential with Theoretical Knowledge}

All studied FBs (nine) had perceived the need to acquire competence on LNG hazards. Interviewees representing seven of the nine FBs stated that the main motivation for initiating learning processes regarding LNG hazards was permanent installations in their jurisdiction area. The two FBs without permanent installations did not initiate learning processes regarding LNG hazards, even though they had experienced LNG-transport accidents.

Shortcomings on theoretical information supplied to the FBs by external consultants were identified, e.g., "It is mainly methane and will move upwards". The facts that the cloud hugs the ground and how variation in relative humidity affects the visible cloud versus the ignitable cloud had not been presented by these external consultants. The focus on wind speed was adequate. The assimilation/accommodation process [54], in order to perceive similarities and differences from 
other similar hydrocarbons (i.e. propane), was therefore only partly completed. This means that they had not reached "reflective observation", stage two in the Kolb learning cycle.

Those who had completed one exercise with actual LNG release had a better understanding (or remembering) of the gas' behavior (five FBs). However, the weather conditions on the particular day determined the behavior of the cloud. The accommodation/assimilation process (stage 2) was performed, but lack of theoretical knowledge as described in Section 2 prevented them from reaching stage 3, abstract conceptualization. In all exercises, they had videotaped the LNG release for future learning. This is valuable, but the differences in the cloud behavior as a function of the weather conditions, especially RH [35], were not revealed.

During a typical experiment, an LNG leak was generated by a hose, while ignition points were placed regularly on the ground, at, e.g., $5 \mathrm{~m}, 10 \mathrm{~m}, 15 \mathrm{~m}$, etc. The observations recorded by different FBs, as to where the leak ignited in relation to the visible cloud, varied. One FB observed that the ignition occurred within the visible cloud and generalized the conclusion: "At least we know where the gas is", i.e., inside the visible cloud. Another FB observed that the ignition occurred outside the cloud and generalized: "The cloud is not as dangerous as the area on the outside of the visible cloud". Thereby, each FB appeared to have generalized the results obtained on the day they performed their exercise. Since no learning cooperation existed between the different FBs, the differences in their observations were not communicated to each other, and the misinterpretations thus remained undetected. The (correct) observations and following (wrong) generalizations demonstrate the shortcoming of observations, when not supported by theoretical knowledge.

One FB performed series of releases, which happened to occur under different weather conditions-summer and winter-thus uncovering, by coincidence, the importance of $\mathrm{RH}$, with respect to the flammable area relative to the visible cloud. The multiple, differing observations led to an astonishment, which did not get resolved before talking with researchers, who first provided a general theoretical explanation for these observations. Later, literature supporting the theoretical considerations and the observations was provided. This was the only FB which completed Kolb's learning cycle and perceived the differences between LNG and other hydrocarbons, as well as the effect of $\mathrm{RH}$ on the observed picture. Since the extent of the visible cloud depends on the ambient air $\mathrm{RH}$, information about flammability can be obtained by combining the visual information (cloud size and position) with the $\mathrm{RH}$ at the time of the release [35].

From a practical point of view, FBs may be called to assist in road incidents involving LNG trucks. Two FBs possessed equipment for assisting LNG trucks and had undertaken exercises with such equipment. One of them had offered demonstrations to a number of other FBs in their region. In this way, it can be said that they had also completed the "operative learning cycle" and had distributed their knowledge to others. The other FB acquired equipment and developed protocols after having handled a road incident successfully, assisted by experts. The cooperative protocol existing in Norway in emergency response leads to responders supporting each other with equipment and competence during emergencies. However, it is always an advantage if responders are familiar with the equipment when the situation demands it.

\subsection{The Learning Process at Hammerfest FB}

Hammerfest FB is located in Finnmark country, in the Arctic area of Norway, at $70.6^{\circ} \mathrm{N}$, a $2+$ hour drive, when the weather conditions allow for crossing the mountain plains, from the neighboring fire brigade in Alta. When an LNG plant was built within their jurisdiction area, a self-planned and self-directed learning project [69] with progressive learning episodes was undertaken, in close cooperation with the distribution company. This process is unique in Norway and is therefore outlined. 


\subsubsection{Competence Goal 1: To Be Able to Handle Small LNG Leaks on the Ground}

This goal was stated as follows: "For example when the tank-truck delivers LNG to a customer, and hoses are perhaps not properly connected when transfer starts, resulting in some LNG spills and possible igniting."

(a) The first learning episode arranged in 2008 included three liters of LNG in a carbon steel jar in an area free from ignition sources. They observed how a visible vapor cloud formed and moved with the wind. During the experiment, the jar cracked, and the remaining LNG leaked to the gravel supporting the jar. This was not intentional learning, but the fact that carbon steel cracks when exposed to cryogenic temperatures was learned. They further used water spray to "direct" the visible cloud towards a particular direction, until it was not visible. They also placed gas detectors in the vicinity of the training field, to detect increased gas concentrations.

(b) The second learning episode was about the same scale, with a stainless steel jar, and the liquid LNG was ignited with a propane burner. Since fire fighters use water to suppress fires in a successful manner in most situations, they therefore wanted to try water on the small LNG fire. As they applied the water jet to the burning liquid, much more gas evaporated, as the cold LNG at $-163{ }^{\circ} \mathrm{C}$ acquired enthalpy from the water. A much larger cloud and larger flame were formed. This was an important lesson for the responders, who had to "unlearn" [70,71] that water is the solution to control most fires. The stainless steel container buckled but did not leak. As the quantity of LNG was small, it was left to burn out.

(c) The third learning episode was to try other extinguishing media to suppress LNG fires and included about 10 liters of LNG. Since water made things worse, it was expected that foam would also act in the same way as water, since it contains much water. That was indeed the case for the foam types examined (they had not tried highly expansive foam). After that, they tried to extinguish the fire with powder, which succeeded with the simultaneous release from several extinguishers. The lesson learned was that it is possible to extinguish an LNG fire with powder, but whether to extinguish must be decided, depending on the situation.

\subsubsection{Competence Goal 2: To Be Able to Handle a Road Incident Involving LNG}

In order to be able to intervene in road incidents involving LNG, the LNG will (normally) be reloaded to another road tanker. This is done both to ease any lifting and to prevent a situation of pressure rise. Cryogenic hoses, pressurized air and flares may be needed, depending on the situation at hand. Hammerfest FB was in possession of an "equipment package" for LNG incidents, and the learning process involved practicing with this equipment.

(d) Learning episode four consisted of performing the procedure of reloading between two tanks. Both tanks were on the training field. Connecting hoses and handling valves were tested. How to judge tank insulation integrity was theoretically comprehended, based on their general understanding of water and frost rime deposits on cold objects.

\subsubsection{Competence Goal 3: Flammability Regions Related to Visible Cloud from LNG Releases}

This goal was related to previous experiments, which had raised the question regarding whether the visible cloud was flammable and/or there were flammable concentrations outside the clouds.

(e) This competence goal evolved during the previous learning episodes. During some of the experiments, gas meters placed on the ground informed that gas was present at long distances $(80 \mathrm{~m})$ ahead of the visible cloud downwind. The lesson was that, although an LNG gas cloud is visible for some time, flammable gas may be present at the ground level for a considerable distance downwind. During other experiments, none of the gas detectors totally submerged in the visible cloud measured flammable conditions. These observations puzzled the responders, who, in the same test field, previously had experienced that gas clouds sometimes could be 
ignited outside and sometimes inside the visible cloud. They were, thus, ready to receive the answer to these phenomena through theoretical considerations by academics, who later supplied the work of Ray [30] and Vílchez et al. [35].

\subsubsection{Competence Goal 4: Learning by Distributing Own Knowledge to Neighboring FBs}

This goal was not explicitly stated, but Hammerfest FB arranged demonstrations and short courses for FBs for all municipalities in Finnmark county having LNG-storage stations or -transportation routes to customers. They also held a demonstration course for the instructors at the Norwegian Fire Academy. During these demonstrations, experience of various cloud sizes and ignition conditions strengthened the needs for goal 3, i.e., understanding where the ignitable gas was, relative to the visible cloud, during LNG releases.

Based on the many releases over several years, the Hammerfest FB also experienced the benefits associated with series exercises, which have previously been identified as important for learning outcomes [72,73].

\subsection{The Learning Process at the other Investigated FBs with Stationary LNG Facilities}

The results indicate that laws and procedures intended to make communities and FBs aware of new hazards [45] were adequate. As the LNG-tank sizes in the studied facilities are above $110 \mathrm{~m}^{3}$, the Directorate of Civil Protection performs yearly audits, while also inviting the local FB to join the sessions. All contacted FBs with permanent LNG-facilities (seven out of nine) were aware of the facilities from the planning process prior to the establishment of the facilities and had participated in audits. However, large variations exist, regarding the degree of responsibility assigned to the respective $\mathrm{FB}$, according to the contingency plan. Responsibilities ranged from full intervention in the site to stopping outside the main entrance and blocking nearby roads for ignition control.

The results indicate that the motivation of different FBs to acquire in-depth knowledge and skill varies, in accordance with the responsibility assigned to them in the contingency plans. However, all of them concluded that the most important motivational factor for learning about the LNG hazard is the fact that the site is permanent. Road transport of several hazardous chemicals through their jurisdiction does not necessarily initialize a thorough learning process on each chemical.

Among the FBs with production facilities in their jurisdiction, the learning process was present, but depth and extension differed. The most thorough learning process (described in Section 6.2) was undertaken by Hammerfest FB, a small FB (ca. 10,000 inhabitants), with responsibility for a large-scale facility, producing 4,200,000 tons of LNG/year. The contingency plan allocates Hammerfest FB the responsibility to respond to incidents in the facility. The fire station is located at a five minute drive from the production plant and there is therefore no industrial fire brigade at the plant. This may have led the FB to strongly perceive themselves as the only resource in incident handling, resulting in a strong feeling of responsibility, thereby completing the Kolb's learning cycle. The large-scale production may also have positively affected the extent of the undertaken learning process. FBs protecting facilities, which were smaller-scale or produced LNG in conjunction with other chemicals, had undertaken less extensive learning processes.

For the storage facilities, the degree of responsibility allocated to FBs by the contingency plan had large variations from case to case. If an LNG incident endangers a factory or the public, the contingency plan assigns more responsibility to FBs than in cases where the storage terminal is quite isolated. In general, the degree of responsibility assigned through the contingency plan may positively affect the extent of the learning process. This observation is in agreement with Tough [69], who states that adult learning projects are undertaken as a response to a task or responsibility which the person faces. Previous familiarity with chemical hazards may not have a clear influence on the process. Although, theoretically, it is an advantage, it may create a feeling of competence without analyzing similarities and differences to other familiar hazards. 
In short, for the other six FBs studied, the learning process was less systematic than for the Hammerfest FB. The FB's responsibility regarding stationary LNG facilities was identified as the main motivational factor for learning.

\subsection{The Learning Process after LNG Road Transport Incidents}

The four Norwegian fire brigades, which had handled road incidents involving LNG tanks, were asked whether the incident had acted as motivation for learning more about the LNG. The unanimous answer was that the incident did not initialize a learning process regarding that particular product and the associated hazards. The seriousness of the incident did not make any difference. (The least serious incident involved an LNG road tanker driving off the road, to terrain without rocks or trees, and the tank was practically empty. This incident was therefore not described in chapter 2.5 , as it practically did not involve LNG and was handled as a regular road accident. The FB handling this incident has also permanent facility and had from before been offered theoretical course and full-scale exercise by the distribution company.)

In the "second-serious" incident, the LNG road tanker tilted towards a rock (Section 2.5.2), which prevented overturning, and the insulation was intact. The LNG cargo was proactively transferred to another tank before any further handling. The incident was thereby handled as a regular road accident. No learning process on the cargo was undertaken or offered by the production or transportation companies involved.

The "third-serious" incident involved overturning, an injured driver, and punctured insulation (Section 2.5.1). The responders were more involved and discussed the handling during the following days but claim that the presence of permanent storage tanks in their jurisdiction was the most important reason for their motivation to learn about LNG, i.e., not the incident. Their answer confirms that the authors' selection of FBs to include in the study, primarily because of stationary installations, is reasonable.

The "fourth-serious" incident involved overturning to lower terrain, punctured vacuum insulation, and a tree penetrating the driver's cabin (Section 2.5.3). It took $46 \mathrm{~h}$, including flaring operations, to handle this incident. The responders systematized their experiences in a PowerPoint presentation, which they presented for the fire stations within their own organization (FB) not involved in the incident. The presentation was then left untouched for three years until it was presented to the author. They did, however, acquire experience and developed procedures that may help them to more effectively handle future road incidents with hazardous chemicals.

The reason for not performing a learning process on the particular cargo can be explained by the low probability of similar road accidents in their area, and that the handled incident is already history. The value of guidance from a highly competent 110 alarm center (equivalent to the US 911 centrals) was underlined in all the cases. In the fourth case, the 110 center staffed up with four extra operators, working only on that particular incident. As 110 centers in Norway currently merge, the responders were concerned about the future possibility of obtaining as good help (longer distances and higher probability of parallel responses). Using Kolb's theory for experiential learning, the incident initialized the circle (experience), for the two most serious cases. Reflection followed, but conceptualization and active experimentation were not undertaken.

In short: handling road incidents involving LNG did not initialize a thorough learning process about the chemical itself.

\subsection{Is There Any Learning Cooperation between FBs?}

Most studied FBs reported that the distribution company or the industry in general was their main learning partner for LNG and similar types of hazardous products. Surprisingly, none of the FBs had previously had contact with any other FBs facing LNG as a challenge, though other FBs had dealt with LNG for more than a decade. This indicates that knowledge sharing has great potential for improvement. None of the interviewed FBs mentioned the authorities as an important partner for 
learning or the coordination of learning among FBs, regarding new hazards. Conclusively, FBs do not exploit the learning potential involved in cooperation with other FBs. As mentioned by Hansen [1], similarity of tasks is a necessary but not adequate factor for learning cooperation.

As a total impression, the Norwegian FBs perceived themselves as devoted to the community they belonged to, rather than as participants in a larger national fire fighter community. One may raise the question as to whether central coordination is necessary to stimulate inter-FB-community learning processes. As stated by Hansen [1], either central coordination or a lateral network is necessary for units in the same organization to exchange knowledge. Common challenges alone are often not enough to initiate knowledge exchange.

A dedicated center, which identifies synergy and promotes cooperation and knowledge exchange, may be recommended [2,4]. The center could also gather relevant literature and international experience, to enrich the basis of competence. In the US, there are guidance documents targeting the knowledge needs of emergency response services on LNG, at least theoretically. The NASF [36,74] covers the properties of LNG from a responder's view and guides FBs in the administrative process, before facilities are established. In the European Union, the "LNG Masterplan for Rhine-Main-Danube" [75] includes a detailed suggestion of knowledge requirements, i.e., understanding and skills, for emergency responders in areas where LNG becomes a part of inland navigation. The scope of the suggested course resembles graded academic courses more than the type of one-day sessions, which are usual for fire brigades in Norway. Who, how, and where, regarding the courses, have to be further determined. A large training facility has also been newly built in the harbor of Rotterdam, The Netherlands. LNG in ships and harbors was, however, not within the scope of the present study.

Another sharing mechanism consists of lateral linkages between units in the organization, which are necessary for an efficient knowledge flow [5,6]. In Norway, the Inter-municipal Cooperation against Environmental Pollution organizes several FBs in larger areas. Knowledge networks can more easily emerge among them. However, as production sites and storage sites are geographically spread, it is unlikely that two or more FBs facing the LNG hazard will be part of the same local network. Thus, "specialized networks" on particular hazards probably need to be centrally coordinated.

It may be more complicated to reach the third stage, abstract conceptualization. Published research on LNG leaks' behavior [35] shows that air relative humidity (RH) greatly affects the extent of the visible cloud, relatively to the ignitable cloud. This means that the understanding from observations on the day of the exercise must be supplemented by theoretical knowledge, in order to gain knowledge valuable in all weather conditions. The stage of abstract conceptualization can be reached through either theoretical knowledge or multiple observations, under different values of $\mathrm{RH}$, so that the differences are revealed. However, if doing that, they would firstly need to know that the RH is an important parameter, in order to solve the puzzle. Assistance from highly qualified personnel is therefore recommended on a general basis, not only for LNG training sessions.

Theoretical knowledge and awareness about relevant published research in the field can improve the safe handling of incidents, provided that FBs are aware of this knowledge. Virtual Reality, Simulation, and Serious Games (VR-SSG) may be a favorable manner to train FBs in handling incidents with hazardous chemicals, especially when weather parameters are important. Through VR-SSG, it is possible to vary the parameters of interest, in much the same way as one varies weather conditions with nautical simulators. Theoretical knowledge is thus implicit in the simulation's scenario, and fire responders can observe the differences by changing the parameters. This will increase learning effectiveness and can be combined with videos from their own experiments. It is therefore suggested that this be given greater attention in future LNG safety research.

\section{Conclusions}

The fire brigades (FBs') learning processes regarding LNG were primarily driven by responsibility for one or more fixed installations. The learning was generally in cooperation with the distribution companies. When getting, e.g., a storage facility in their jurisdiction, no attempt was made to learn 
from other FBs, not even from those with decades of experience with LNG. Only one FB had completed Kolb's learning cycle. This FB had been able to construct their own knowledge; however, this was not completed until they invited their academic partners to the training field. Then, the theory behind answers to previously surprising observations was presented and, later, followed up by reference to the international literature. Producing their own knowledge resulted in a feeling that the knowledge belonged to them and they could "pass it on to other FBs", in the form of courses and demonstrations. This strongly contrasted with the FBs, who "got a course arranged by a local company" and, later, felt that they "had learned just enough" and had "nothing to pass on" to others. Most FBs gave the impression of not going sufficiently deeply into the differences between LNG and other hydrocarbons. The fact that cold LNG vapor cools down the surrounding air and results in a gas air mixture heavier than the ambient air, hugging the ground, was not comprehended. As LNG mainly consists of methane, it was stated that "The lighter gas will rise and not make any trouble". A knowledge center exploring new hazards and initiating national learning processes at FBs would be very beneficial.

Funding: This research received no external funding.

Acknowledgments: The valuable information supplied by the interviewees is greatly appreciated. The discussions with Morten Sommer, Western Norway University of Applied Sciences, and T. Log, Equinor, Kårstø and Hammerfest LNG, Norway, are much appreciated.

Conflicts of Interest: The authors declare no conflict of interest.

\section{References}

1. Hansen, M.T. Knowledge networks: Explaining effective knowledge sharing in multiunit companies. Organ. Sci. 2002, 13, 232-248. [CrossRef]

2. Farjoun, $M$. The independent and joint effects of the skills and physical bases of relatedness in diversification. Strateg. Manag. J. 1998, 19, 611-630. [CrossRef]

3. Markides, C.; Williamson, P. Related diversification, core competence and corporate performance. Strateg. Manag. J. 1994, 15, 149-167. [CrossRef]

4. Chandler, A. The functions of the HQ unit in the multibusiness firm. In Fundamental Issues in Strategy; Rumelt, R.P., Schendel, D.E., Teece, D.J., Eds.; Harvard Business School Press: Boston, MA, USA, 1994; pp. 191-215, ISBN 0875843433.

5. Gupta, A.K.; Govindarajan, V. Knowledge flows within multinational corporations. Strateg. Manag. J. 2000, 21, 473-496. [CrossRef]

6. Hansen, M.T. The search-transfer problem: The role of weak ties in sharing knowledge across organization subunits. Admin. Sci. Quart. 1999, 44, 82-111. [CrossRef]

7. NOU. New Education for New Challenges. Comprehensive Education Model for Future Personnel in the Fire Brigades; (No. Ny Utdanning for nye Utfordringer. Helhetlig Utdanningsmodell for Fremtidig Personell i Brannvesenet); Norges Offentlige Utredninger: Oslo, Norway, 2012; Volume 8, 174p, ISBN 978-82-583-1136-9.

8. MJPa. Regulations on Organization and Dimensioning of the Fire Departments; (No. Forskrift om Organisering og Dimensjonering av Brannvesen), Norwegian Ministry of Justice and Public Security, FOR-2002-06-26-729; Government of Norway: Oslo, Norway, 2002.

9. Sommer, M.; Njå, O. Learning amongst Norwegian Fire fighters. J. Workplace Learn. 2011, 23, 435-455. [CrossRef]

10. Karagiannis, G.M.; Synolakis, C. Twenty challenges in incident planning. J. Homel. Secur. Emerg. Manag. 2017, 20160061, 12. [CrossRef]

11. Lipshitz, R.; Strauss, O. Coping with uncertainty: A naturalistic decision making analysis. Organ. Behav. Hum. Decis. Process. 1997, 69, 149-163. [CrossRef]

12. Van den Heuvel, C.; Alison, L.; Power, N. Coping with uncertainty: Police strategies for resilient decision-making and action implementation. Cogn. Technol. Work 2014, 16, 25-45. [CrossRef]

13. Kolb, D.A. Experiential Learning: Experience as the Source of Learning and Development; Prentice Hall: Englewood Cliffs, NJ, USA, 1984; ISBN 0133892409.

14. EIA. Annual Energy Outlook 2018; U.S. Energy Information Administration: Washington, DC, USA, 2018; 74p. 
15. Molnar, G.; Behrens, A.; Egenhofer, C.; Genoese, F. Europe's LNG Strategy in the wider EU Gas Market, Center for European Policy Studies. Ceps Policy Brief 2015, 10, 333.

16. Wainberg, M.; Mishot, F.M.; Gülen, G.; Quijano, D. Current and Future Natural Gas Demand in China and India; Center for Energy Economics, The University of Texas at Austin: Austin, TX, USA, 2017; 133p.

17. Enova. Small Scale LNG Facilities in Norway; (No: Småskala LNG i Norge); Enova SF: Trondheim, Norway, 2016. (In Norwegian)

18. EGN. Norwegian Coast LNG. Development of Infrastructure for LNG as Fuel in Norway; (No. Norskekysten LNG. Utvikling av Infrastruktur for LNG Som Drivstoff i Norge); Energigass Norge: Avaldsnes, Norway, 2015. (In Norwegian)

19. NHO. Report on Fulfilment of Reduction Obligation for 2017 According to Environmental Agreements on NOx 2011-2017; (No. Rapport om oppfyllelse av forpliktelsene i reduksjon av NOx-utslipp for 2012 i miljøavtalen om NOx 2011-2017); Næringslivets NOx-fond: Oslo, Norway, 2013.

20. Johnsen, T. Status and Future of the NOx-fund (No. NOx-fondets Status og fremtid). In Proceedings of the Gasskonferansen-15, Oslo, Norway, 24-25 March 2015. (In Norwegian)

21. Drysdale, D. An Introduction to Fire Dynamics, 3rd ed.; John Wiley \& Sons Ltd.: New York, NY, USA, 2011; ISBN 978-0-470-31903-1.

22. Nizamoglu, M.; Tan, A.; Vickers, T.; Segaren, N.; Barnes, D.; Dziewulski, P. Cold burn injuries in the UK: The 11-year experience of a tertiary burn centre. Burn. Trauma 2016, 4, 1-8. [CrossRef] [PubMed]

23. GIIGNL. The Global Market for Liquefied Natural Gas. Int. Group Liq. Nat. Gas Import. Bull. 2011, 9, $17-27$.

24. Gyenes, Z.; Wood, M.H.; Struckl, M. Handbook of Scenarios for Assessing Major Chemical Accident Risks; Joint Research Center Technical Reports; EUR 28518 EN; European Commission: Ispra, Italy, 2017; 116p, ISBN 978-92-79-66670-4. [CrossRef]

25. Malvos, H.; Raj, P.K. Thermal emission and other characteristics of large Liquified Natural Gas fires'. Process Saf. Prog. 2006, 26, 237-247. [CrossRef]

26. Blanchat, T.; Helmick, P.; Jensen, R.; Luketa, A.; Deola, R.; Suo-Anttila, J.; Mercier, J.; Miller, T.; Ricks, A.; Simpson, R.; et al. Summary of the PHOENIX series large-scale LNG pool fire experiments. In Proceedings of the 23rd International Colloquium on the Dynamics of Explosions and Reactive Systems (ICDERS), University of California, Irvine, CA, USA, 24-29 July 2011.

27. Luketa-Hanlin, A. A review of large-scale LNG spills: Experimental and modelling. J. Hazard. Mater. 2006, 132, 119-140. [CrossRef] [PubMed]

28. Wang, C.J.; Wen, J.X.; Chen, Z.B. Simulation of large-scale LNG pool fires using FireFoam. Combust. Sci. Technol. 2014, 186, 1632-1649. [CrossRef]

29. Raj, P.K. LNG fires: A review of experimental results, models and hazard prediction challenges. J. Hazard. Mater. 2007, 140, 444-464. [CrossRef] [PubMed]

30. Raj, P.K. Where in a LNG vapour cloud is the flammable concentration relative to the visible cloud boundary? NFPA J. 2006, 5/6, 68-70.

31. Koopman, R.P.; Ermak, D.L. Lessons learned from LNG safety research. J. Hazard. Mater. 2007, 140, 412-428. [CrossRef]

32. Ermak, D.L.; Chan, S.T.; Morgan, D.L.; Morris, L.K. A comparison of dense gas dispersion model simulation with Burro series LNG spill test results. J. Hazard. Mater. 1982, 6, 129-160. [CrossRef]

33. Koopman, R.P.; Cederwall, R.T.; Ermak, D.L.; Goldwire, H.C.; Hogan, W.J.; McClure, J.W.; McRae, T.G.; Morgan, D.L.; Rodean, H.C.; Shinn, J.H. Analysis of Burro series $40 \mathrm{~m}^{3}$ LNG spill experiments. J. Hazard. Mater. 1982, 6, 43-83. [CrossRef]

34. Blackmore, D.R.; Eyre, J.A.; Summers, G.G. Dispersion and combustion behavior of gas clouds resulting from large spillages of LNG and LPG on to the sea. Inst. Mar. Eng. Trans. 1982, 94, 2-18.

35. Vílchez, J.A.; Villafañe, D.; Casal, J. A dispersion safety factor for LNG vapor clouds. J. Hazard. Mater. 2013, 246, 181-188. [CrossRef] [PubMed]

36. Emerson, W.; Felleisen, T.; Frederick, M.; Grosshandler, W.; Henry, B.; Licata, P.; Mohn, J.; Smith, M. Liquefied Natural Gas: An Overview of the LNG Industry for Fire Marshals and Emergency Responders; National Association of State Fire Marshals: Washington DC, USA, 2005; 23p.

37. NPA. The Norwegian Petroleum Authority. 2018. Available online: www.ptil.no/granskinger/gransker-lnglekkasje-pa-hammerfest-lng-article13792-717.html (accessed on 1 July 2018). 
38. MFAME. LNG Carrier Damaged After Grounding. Available online: http://mfame.guru/lng-carrierdamaged-grounding/ (accessed on 24 April 2017).

39. Kalogeraki, E.-M.; Papastergiou, S.; Mouratidis, H.; Polemi, N. A novel risk assessment methodology for SCADA maritime logistics environments. Appl. Sci. 2018, 8, 1477. [CrossRef]

40. Planas-Cuchi, E.; Gasulla, N.; Ventosa, A.; Casal, J. Explosion of a road tanker containing liquefied natural gas. J. Loss Prev. Process Ind. 2004, 17, 315-321. [CrossRef]

41. Bonilla Martinez, J.M.; Belmonte Peréz, J.; Marin Ayala, J.A. Analysis of the Explosion of A Liquefied-Natural-Gas Road-Tanker. Available online: http:/ / www.mapfre.com/fundacion/html/revistas / seguridad/n127/en/article2.html (accessed on 10 October 2018).

42. Hagesæter, E.; Vaksdal, B. Tankbil veltet på Osvegen. BergensAvisen, 14 May 2010. Available online: www.ba.no/nyheter/tankbil-veltet-pa-osvegen/s/1-41-5115655(accessed on 29 June 2018).

43. Wærstad, H. En Tankbil Med Brannfarlig Gass har Kjørt av Veien i Vinje. NRK Telemark, 2011. Available online: https: / / www.nrk.no/telemark/tankbil-med-gass-i-grofta-1.7510648 (accessed on 5 July 2018).

44. Fagerland, O.A. Turnover between Gvarv and Ulefoss 13/10-15; (No. Rundvelt mellom Gvarv og Ulefoss 13/10-15), Gasnor/Shell; Gasnor: Avaldsnes, Norway. (In Norwegian)

45. MJP. Regulations on Municipal Emergency Preparedness; (No. Forskrift om kommunal beredskapsplikt); Ministry of Justice and Public Security, Government of Norway: Oslo, Norway, 2011.

46. MJP. Regulations on Measures to Prevent and Limit the Consequences of Major Accidents in Activities Involving Hazardous Chemicals; (No. Forskrift om tiltak for å forebygge og begrense konsekvensene av storulykker i virksomheter der farlige kjemikalier forekommer); Norwegian Ministry of Justice and Public Security, Government of Norway: Oslo, Norway, 2016.

47. $\mathrm{MJPb}$. Law on Fire Protection, Explosion and Accidents Involving Hazardous Substances; (No. Lov om vern mot brann, eksplosjon og ulykker med farlig stoff); Norwegian Ministry of Justice and Public Security, Government of Norway: Oslo, Norway, 2002.

48. MJP. Regulation on Fire Prevention and Inspections; (No. Forskrift om brannforebygging); Norwegian Ministry of Justice and Public Security, Government of Norway: Oslo, Norway, 2015.

49. DSB. Guidance to Regulations on the Organization and Dimensioning of the Fire Department; Norwegian Directorate for Civil Protection: Tønsberg, Norway, 2003.

50. Argyris, C.; Schön, D.A. Organizational Learning: A Theory of Action Perspective; Addison-Wesley: Reading, MA, USA, 1978; ISBN 0201001748.

51. Senge, P.M. The Fifth Discipline: The Art and Practice of the Learning Organization; New South Wales: Random House, NY, USA, 1990; ISBN 0-385-51725-4.

52. Pedler, M.; Burgoyne, J.; Boydel, T. The Learning Company: A Strategy for Sustainable Development; McGraw-Hill: London, UK, 1991; ISBN 0077093003.

53. Senge, P.M.; Kleiner, A.; Roberts, C.; Ross, R.; Smith, B.J. The Fifth Discipline Fieldbook; Strategies and Tools for Building a Learning Organization; Doubleday: New York, NY, USA, 1994; ISBN 0385472560.

54. Piaget, J. The Principles of Genetic Epistemology; Routledge: London, UK, 1972; ISBN 100710072961.

55. Skinner, B.F. Science and Human Behavior; The Free Press: New York, NY, USA, 1965; ISBN 9780029290408.

56. Ormrod, J.E. Human Learning, 5th ed.; Pearson/Merrill Prentice Hall: Upper Saddle River, NJ, USA, 2008; 534p, ISBN 0132595184.

57. Lave, J.; Wenger, E. Situated Learning, Legitimate Peripheral Participation; Cambridge University Press: Cambridge, UK, 1991; ISBN 9780521423748.

58. Wenger, E. Communities of Practice, Learning, Meaning and Identity; Cambridge University Press: Cambridge, UK, 1998; 318p, ISBN 9780521663632.

59. Sfard, A. On two metaphors on learning and the dangers of choosing just one. Educ. Res. 1998, $27,4-13$. [CrossRef]

60. Taber, N.; Plumb, D.; Jolemore, S. "Grey" areas and "organized chaos" in emergency response. J. Workplace Learn. 2008, 20, 272-285. [CrossRef]

61. Kolb, A.; Kolb, D.A. Experiential learning theory: A dynamic, holistic approach to management learning, education and development. In The Sage Handbook of Management Learning, Education and Development; Armstrong, S., Fukami, C., Eds.; SAGE Knowledge: Boston, MA, USA, 2009.

62. Bandura, A. Social Learning Theory; Prentice Hall: Englewood Cliffs, NJ, USA, 1977; ISBN 0138167443.

63. Ashworth, P. Being competent and having competencies. J. Further Higher Educ. 1992, 16, 8-17. [CrossRef] 
64. Sommer, M. Learning in Emergency Response Work. Ph.D. Thesis, University of Stavanger, Stavanger, Norway, 2015.

65. Gilham, B. Research Interviews, the Range of Techniques; McGraw-Hill Education: London, UK, 2005; ISBN 9780335215867.

66. Kvale, S. Interviews. An Introduction to Qualitative Research Interviewing, 2nd ed.; Sage Publications: Thousand Oaks, CA, USA, 2004; ISBN 9780803958203.

67. Bryman, A. Social Research Methods, 5th ed.; Oxford University Press: Oxford, UK, 2015; ISBN 9780199689453.

68. Bernard, H.R. Research Methods in Anthropology: Qualitative and Quantitative Methods, 6th ed.; Rowman and Littlefield: Lanham, MD, USA, 2017.

69. Tough, A. The Adult's Learning Projects, A Fresh Theory and Practice in Adult Learning; The Ontario Institute for Studies in Education: Toronto, ON, Canada, 1971; 199p, ISBN 0-7744-0059-5.

70. Hedberg, B. How organizations learn and unlearn. In Handbook of Organizational Design; Nystrom, P., Starbuck, W.H., Eds.; Cambridge University Press: London, UK, 1981; Volume 1, ISBN 9780198272410.

71. Becker, K.L. Facilitating unlearning during implementation of new technology. J. Organ. Chang. Manag. 2010, 23, 251-268. [CrossRef]

72. Metallinou, M.M. Single- and double-loop organizational learning through a series of pipeline emergency exercises. J. Contingencies Crisis Manag. 2017, 26, 530-543. [CrossRef]

73. Van Laere, J.; Lindblom, J. Cultivating a longitudinal learning process through recurring crisis management training exercises in twelve Swedish municipalities. J. Contingencies Crisis Manag. 2018. [CrossRef]

74. NASF. Fire Service Guidance for Participating in LNG Terminal Evaluation, Siting and Operations; National Association of State Fire Marshals: Washington, DC, USA, 2007; 80p.

75. TEN-T. LNG-Masterplan for Rhine-Main-Danube; D2.4.4 Emergency and Incident Response Study; Trans-European Transport Network, European Commission: Brussels, Belgium, 2015.

(C) 2019 by the author. Licensee MDPI, Basel, Switzerland. This article is an open access article distributed under the terms and conditions of the Creative Commons Attribution (CC BY) license (http://creativecommons.org/licenses/by/4.0/). 